\title{
Research on Historical Background of Scientific Research Evaluation System in German Universities
}

\author{
Lihong Li \\ School of Humanities and Law \\ Northeastern University \\ Shenyang, China 110819 \\ Liaoning TV and Radio University \\ Liaoning Vocational College of Equipment Manufacture \\ Shenyang, China 110161
}

\author{
Wanbing Shi \\ School of Humanities and Law \\ Northeastern University \\ Shenyang, China 110819
}

\begin{abstract}
The exploration and analysis on historical background of scientific research evaluation system in German universities has great significance and value to understand the evolution of scientific research evaluation in German universities. The historical background that the scientific research evaluation system in German universities establishes and develops is analyzed from the perspective of historical analysis through definition of core concepts, the introduction of scientific research as function of universities into higher education, the introduction of academic freedom as guarantee of higher education into legislation, the strict selection system of teachers in German universities and the German excellence program, in order to make an in-depth exploration on cultural and historical foundation of scientific research evaluation in German universities.
\end{abstract}

Keywords-Germany; universities; scientific research; evaluation system; historical background; academic freedom; excellence program

\section{INTRODUCTION}

Germany is the headstream of modern universities. Humboldt founded University of Berlin in 1810, combining teaching with scientific research and advocating academic freedom. The combination of teaching with scientific research becomes the soul of modern universities, points out new direction for higher education development and creates patterns for modern universities, having far-reaching influence on world higher education. German universities take scientific research as the basic function and bring it in. However, for decades, German higher education system devotes to maintaining the myth that "the education quality of all universities is the same". The evaluation on scientific research took a place in the 1990s, later than other European countries and America. The development process is slow. Therefore, we should make in-depth research on profound historical background of evaluation system of scientific research in German universities, in order to better understand the development history, characteristics and strength of

Fund project: the education project of national social science fund "Research on Evaluation System of Scientific Research of Teachers in Humanistic and Social Science in Universities" (Project No.: BFA150043). scientific research evaluation system in Germany.

The scientific research evaluation system in German universities forms and develops with the increasingly close relationship of mutual dependence between German universities and social development. German universities depend on government and society to provide scientific research funds. Society and government depend on the capacity for scientific research of universities to provide power of social development. Therefore, scientific research evaluation has become crucial since the 1990s. Besides, the scientific research system realizes the strategic development goal of universities through assessment of scientific research quality and improvement of research efficiency and quality. With more attention paid to scientific research evaluation, Germany gradually forms the scientific research evaluation system including government agencies (Federal Ministry of Education and Research), the third party organizations (The German Council of Science and Humanities, Deutsche Forschungs Gemeinschaft, The Center for Higher Education Development, Humboldt Stiftung) and self-assessment of universities. In 2013, Germany's Research Rating Will Make Quality Its Own Reward was published on Times Higher Education, to explore the characteristics of scientific research evaluation system and its significance on academic research in Germany. This historical background of scientific research evaluation system in German universities is analyzed through the introduction of scientific research as function of universities into higher education, the introduction of academic freedom as guarantee of higher education into legislation, the strict selection system of teachers in German universities and the German excellence program.

\section{INTRODUCTION OF SCIENTIFIC RESEARCH AS FUNCTION OF UNIVERSITY INTO HIGHER EDUCATION}

The principle of "unification of research and teaching" proposed by Humboldt, the pioneer of higher education reform in Germany still serves as the guiding thought of German universities. Humboldt observes the main task of universities is to seek the truth. Scientific research is the priority among priorities. Without scientific research, it is impossible to develop science and train scientific talents. The 
science said by Humboldt is the all-inclusive ultimate discipline that makes intellectual enquiries and dominates all disciplines, referring to the pure philosophy. Scientific research is to research the theoretical, explanatory or philosophical pure science. The researches have the value of "culture". "However, scientific research is to make teaching more creative and rigorous as well as richer and realize benign interaction between it and teaching.

The University of Berlin founded under the idea of Humboldt values the academic achievements of teachers. Teachers and students are researchers. Claudius Geller expresses in discussion on teaching and scientific research in Germany, "the unification of scientific research and teaching stipulates the professional task of university teachers. Their teaching will closely combine with scientific research and establish on the basis of scientific research. University teachers should concentrate on scientific research. Their opinions and achievements in scientific research should directly become their teaching property. Furthermore, university teachers are obliged to carry out scientific research, the achievements of which should be applied to teaching." [1]

Humboldt does not take teaching as the only function of universities but bring in scientific research as the basic function of universities. The idea decides universities are institutions for academic research. The learning and research on pure knowledge forms the good way of thinking and characters of students. Called as "the nursery garden of scientific research", the seminar method encourages students to do scientific research.

Humboldt's idea of scientific research is not outdated till today. The pursuit of pure science is still the internal motivation of the development of German universities. Scientific research is the ultimate duty of scholars as well as the indispensable responsibility of excellent university teachers

\section{THE INTRODUCTION OF ACADEMIC FREEDOM AS GUARANTEE OF HIGHER EDUCATION INTO LEGISLATION}

Humboldt thinks the premise of pursuing pure knowledge is freedom, including the freedom of teaching and learning. Freedom means teachers are free to discuss, find, publish and teach the truth found in professional fields of their own. The freedom of teaching is neither subject to any restriction nor commanded by any authority and intervened by public opinions related to politics, political parties and groups..." [2] The freedom of learning means "students are free to discuss, doubt, disagree and criticize the authority on professional learning under the guidance of correct methods, have the rights to choose teachers and what to learn as well as comment on educational management..." [2] The key factor of academic freedom is to take free exploration as the core values of universities.

"Teaching freedom (academic freedom)" and "combination of teaching and scientific research" are the core ideas of Humboldt University of Berlin. Humboldt lets the spirit of academic freedom run through universities, which promote the development of modern universities. It is the most important foundation to establish the idea of university. Paulsen addresses, "Professors must be independent scholars. Teaching shouldn't carry out according to definite sequence but the freedom of teaching and learning, in order to teach real scientific culture instead of encyclopedic information. Students are not treated as the server of state officials but treated as young people. The unrestricted scientific learning trains their reason of independent thinking and moral freedom". [3] According to the educational objectives of the development and exploration of knowledge, Humboldt founded and developed the corresponding university system: university autonomy, academic freedom, university management by professors, elective system and private lecturer.

Germany is the first country in the world that endows university with academic freedom in constitution. In 1919, Article 142 of German Weimar Constitution stipulated, "Art, science and scientific law are free. The country shall protect and cultivate." [4] Afterwards, Item 3 in Article 5 of Basic Law for the Federal Republic of Germany (GG, Grundgesetz) stipulates "Art and academy, research and teaching are free. Teaching freedom shall not be exempted from the loyalty to the constitution". [4] In 1976, the General Law of Universities in Federal Germany defined "research freedom, teaching freedom and learning freedom" as the three freedoms followed by various countries in the world.

\section{StRict Selection SySTEM OF TEACHERS IN GERMAN UNIVERSITIES}

\section{A. The General Law of Higher Education in Germany} Stipulates the Qualification of Teaching in Universities

It stipulates professors independently carry out scientific research and teaching according to specific requirements of posts. Professors participate in teaching reform and academic consultation, school management and host examinations. Universities cannot dismiss professors even facing financial crisis and recombination. As the transitional academic post to professors, teaching assistants should have doctorate and can do scientific research and teaching independently. Contract teachers are the personnel cooperating with professors in teaching and scientific research, having no restriction in employment period. The requirement of academic appointment is to obtain teaching qualification in universities. Qualified persons should be able to do research independently and make creative contributions. Therefore, teaching qualification ensures the professors are competent researchers in German universities.

\section{B. Private Lecturer System in German Universities}

A characteristic teacher selection system in German universities is the private lecturer system. In order to embark on academic road, young scholars must get doctorate through academic dissertation and pass the examination of teaching quality in universities. And then he is qualified to apply for teaching qualification in universities to become a private lecturer. Private lecturers do researches of their own and only collect class fees instead of being paid by the university. The work of private lecturers bases on their sense of mission and 
inner pursuit. They provide an academic cradle for German universities.

\section{German Universities Implement the Ban of Retaining A Post in Universities}

It is expressly stipulated in the General Law of Higher Education in Germany that professors must be recruited and selected by other universities. Universities will consider school staff on special occasions. Therefore, if teachers in German universities want to get promotion, they have to be employed by other universities. It is nearly impossible to get promotion in the present unit. It improves teaching quality and promotes the development of scientific research. Although the ban has been cancelled, in order to prevent petticoat influence, German universities still implement in reality.

\section{Introduce Junior Professoriate System}

The system makes young scientists and scholars immediately do research and teaching independently after doctoral dissertation defense. Afterwards, they are qualified to apply for routine professoriate. It is an important measure that acts on international convention.

\section{E. German Universities Establish University Research Board in Regulations}

University Research Board in University of Munich is permanent committee established to promote scientific research and train reserve force of scientific research. It gives advice and support related to inter-disciplinary research and basic research for school leadership, enlarged meeting of school representative and appraisal meeting, especially making proposals for control of research quality, promotion and coordination of research plan and key points. Furthermore, University of Munich establishes academic investigation committee, which is a permanent committee to register and investigate incidents that break academic norms. If the suspicion of academic violations exists according to the pre-investigation of self-inspection commissioner in the school, it submits suggestions related to treating methods of incidents.

\section{F. German Universities Pay Attention to Training Reserve Force of Scientific Research}

For example, it stipulates in Article 22 of Humboldt University of Berlin Chapter: professors and middle-level teachers at least account for one third respectively in the special committee of scientific research and academic reserve force. [5] Part nine in Regulations of Ludwig Maximilian Muenchen Universitaet is related to the training of reserve force for scientific research. It stipulates in Article 44 that universities devote to training reserve force for scientific research and provide enough opportunities for them in scientific work. Moreover, universities should carry out inter-disciplinary activities or activities through cooperation with other universities to strengthen the ability to train reserve force for scientific research.

\section{EXCELLENCE PROGRAM IN GERMANY}

In June 2005, German federal and state governments passed the excellence program focusing on research-oriented universities and research fields, in order to revive the supreme academic status of Germany. The purpose is to "strengthen the top research level of Germany and international competitiveness". The excellence program subsidizes the following three excellent programs:

- Graduierten-schulen program, devoting to training young reserve forces for scientific research

- Exzellenzcluster program, in order to promote frontier scientific research

- Zukunftskonzepte program, in order to expand the frontier scientific research in universities

Researchers think there are no elite educational institutions in Germany and graduates have no great differences in employment and promotion. However, the core of German excellence program is to train talents. It distinguishes excellent universities from regular universities through evaluation on scientific research of them. Except for paying attention to regular selection indicators like the quality of scientific research, the excellence program also attaches importance to multidisciplinary research methods and interdisciplinary cooperation. Under the background of popularization of higher education and limited educational investment in Germany, capitals are invested in universities with strong scientific strength in order to help them to rapidly develop into the world's top universities.

\section{CONCLUSION}

To sum up, German educator Humboldt has strongly advocated higher education and university teachers in Germany to pursue scientific research. Scientific research is the responsibility of university teachers. Academic freedom, the premise for university teachers to carry out scientific research is guaranteed by law. The strict selection system of German academic teaching staff ensures they can get enough training. The doctorate proves they have research ability. They have to spend nearly ten years to be qualified to teach in universities. Just as American educator Altbach said, in Germany, Russia and other countries that follow German academic pattern, teachers have to own the second doctorate or equivalent qualifications to obtain the post of full professor. [6] Therefore, traditionally, there is no need to examine the scientific research of teachers in German universities. The higher education system in Germany does have high academic standard. The internal need of scientific research evaluation system in German universities is later than other European countries and America in educational reform and practice.

With social and economic development, the popularization of German higher education and investment of limited funds, increasing attentions are paid to benefit and efficiency of scientific research. German government seeks the development of world first class universities. German Scientific Committee began to evaluate the research 
performance of German universities and academic institutions. Excellence program was launched in June 2005, referring to the selection system of universities to distribute government funds according to evaluation of the capacity for scientific research in universities. It values the training of young scholars and invests in the future research potential to ensure young students have the best opportunity of academic development and establish excellent research standard. It emphasizes in the Basic Law of Higher Education revised in 2006, "Universities shall accept regular assessment in scientific research, teaching, and the training of academic reserve talents and promotion of gender equality. Students shall participate in it and publicize the assessment result". [7] These measures are the first step for assessment of teaching and scientific research to move towards "quality assurance system of academic service". Germany is establishing characteristic national-level assessment system and the scientific research evaluation system of schools. Universities will change from equal balanced development to competitive imbalanced development. Scientific research evaluation will gradually become national conventional practice, which will influence the overall development of higher education in Germany. "Scientific research plays an increasingly important role in recent years. Most experts think universities differentiate according to scientific research functions." [8] The efficient scientific evaluation system in Germany will serve as the auxiliary means of government and academic institutions like universities to distribute funds and make great decisions as well as meet national needs.

\section{REFERENCES}

[1] (America) Burton R. Clark, Scientific Research Basis of Postgraduate Education $[\mathrm{M}]$, translated by Wang Chengxu. Hangzhou: Zhejiang Education Publishing House, 2001

[2] Wang Jianhua. From Idea to System: Rethinking on "University Autonomy and Academic Freedom" [J], Journal of Qingdao Institute of Chemical Technology (Social Sciences Edition), 2001(03):7

[3] Burton R. Clark, Scientific Research Basis of Postgraduate Education $[\mathrm{M}]$, translated by Wang Chengxu. Hangzhou: Zhejiang Education Publishing House, 2001, P8

[4] Hu Jinguang, Han Dayuan. Contemporary Protection of Human Rights [M], Beijing: China University of Political Science and Law Press, 1993: 164

[5] Zhang Guoyou, Volume II of Magna Charta Universitatum, Peking University Press, editor-in-chief, published in Octobor 2011, P251, P228, P263

[6] America, Philip G. Altbach, International Trend of Higher Education Reform, Peking University Press, translated by Jiang Kai, published in November 2009, P123

[7] Hochschulrahmengesetz, 6. (Article 6 of Basic Law of Higher Education), final revision in Apr.12, 2007

[8] Teichler, U.Hochschulstrukturen im Umbruch. Eine Blianz der Reformdynamik seit vier Jahrzehnten[M]. Frankfurt am Main: Capmpus Verlag, 2005: 10 